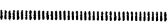

\section{Liquid Phase Diffusion Bonding of a Nickel-base Oxide Dispersion Strengthened Alloy MA 754}

Teruo Hirane, Shogo Morimoto and Takao Funamoto

\section{Synopsis :}

The ODS alloy(MA754) produced by mechanical alloying was joined by a Liquid phase diffusion bonding method under a low compressive stress using an amorphous insert ribbon metal with small thickness. Microstructural features, concentration of alloying elements and mechanical properties of bonded area were examined.

1) Dispersed $\mathrm{Y}_{2} \mathrm{O}_{3}$ particles coagulated at the bonded interface in the process of isothermal solidification. However, the amorphous ribbon of insert metal with elements to lower the melting point produced a sound structure without any voids.

2) The rate of interface diffusion between the insert metal and the base metal was influenced by the element added to lower the melting point of insert metal.

3) The fractured position of specimens tested in tension was changed to base metal position at elevated temperatures. The transition temperature depended on the element added to lower the melting point of insert metal.

4) The creep rupture life at $982^{\circ} \mathrm{C}$ of bonded alloy was more than $85 \%$ of that of the base metal.

\section{1. 緒言}

航空機エソジン，ガスタービンなどの効率向上をはか るため,より高温で, しかも苛酷な状態のもとに使用で きる耐熱材料が要求されている．超合金マトリクスに微 粒子を分散させて高温での強化を狙つた粒子分散合金は 次期耐熱材料の一つと考えられている。とくに，ょカ二 カルアロイング製法により開発された1) 5)酸化物分散強 化合金 (Oxide Dispersion Strengthened Alloy : ODS 合金）は $\gamma^{\prime}$ 相析出強化超合金よりも約 $100^{\circ} \mathrm{C}$ 酎用温 度が高いといわれ3 〜 ) タービン翼材料としての実用化 が望まれている.

この ODS 合金は鋳造すると酸化物粒子の均一㸮布が 失われ, ODS 合金としての特性がなくなるので, 複雑 な内孔を有するタービン翼の製造には接合強度を低下さ せない払散接合法の適用が好ましい。そこで，耐熱超合 金, とくに $\gamma^{\prime}$ 相を析出して強化するタービン翼用超合 金に有効と目されるインサート金属を用いての液相昖散 接合6) 11)をこの ODS 合金に適用し，その効果を確か めた。

液相拡散接合は接着媒体として薄膜6）または粉末7)の

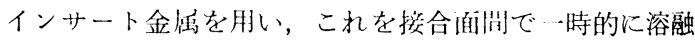
乙等賉㠜湖とその後のインサート金属と性材との相互成 分抁散により坫成するものであり，インサート金属が接 合の成令を沈める们装な鍵をにぎつている。このインサ

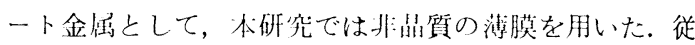
来，非昆質溥膜は膜高の均一化，作意形状の打抜性など 種々の機能があり，束た，接合激の健全性も確保できる とい才れて ${ }^{11)}$ いる，そこで，本研究では，化学成分を 2 〜3 変えた非晶質湍膜を作製し，これを $\mathrm{Y}_{2} \mathrm{O}_{3}$ 粒子で強 化した ODS 合金に適用できるかどらかを、腿に調べ た。なお，接合渭度と時间を㚆えた場合の接合性質につ いても調夜したので報售する。

\section{2. 実 験 方 法}

\subsection{ODS 合金}

実験に用いた ODS 合金の化設成分を Table 1 に示

Table 1. Chemical composition of ODS alloy (wt $\%)$.

\begin{tabular}{c|c|c|c|c|c|c}
\hline $\mathrm{Cr}$ & $\mathrm{Y}_{2} \mathrm{O}_{3}$ & $\mathrm{Ti}$ & $\mathrm{Al}$ & $\mathrm{C}$ & $\mathrm{Fe}$ & $\mathrm{Ni}$ \\
\hline 19.76 & 0.56 & 0.42 & 0.36 & 0.07 & 0.99 & $\mathrm{Bal}$ \\
\hline
\end{tabular}

昭和 59 年 4 月 10 月本会講演大会にて発表 牟和 60 年 10 月 9 日受付 (Received Oct. 9, 1985)

*（株）日立製作所日立研究所 (Hitachi Research Laboratory, Hitachi, Ltd., 832-2 Horiguchi

Katsuta Ibaraki pref. 312) 


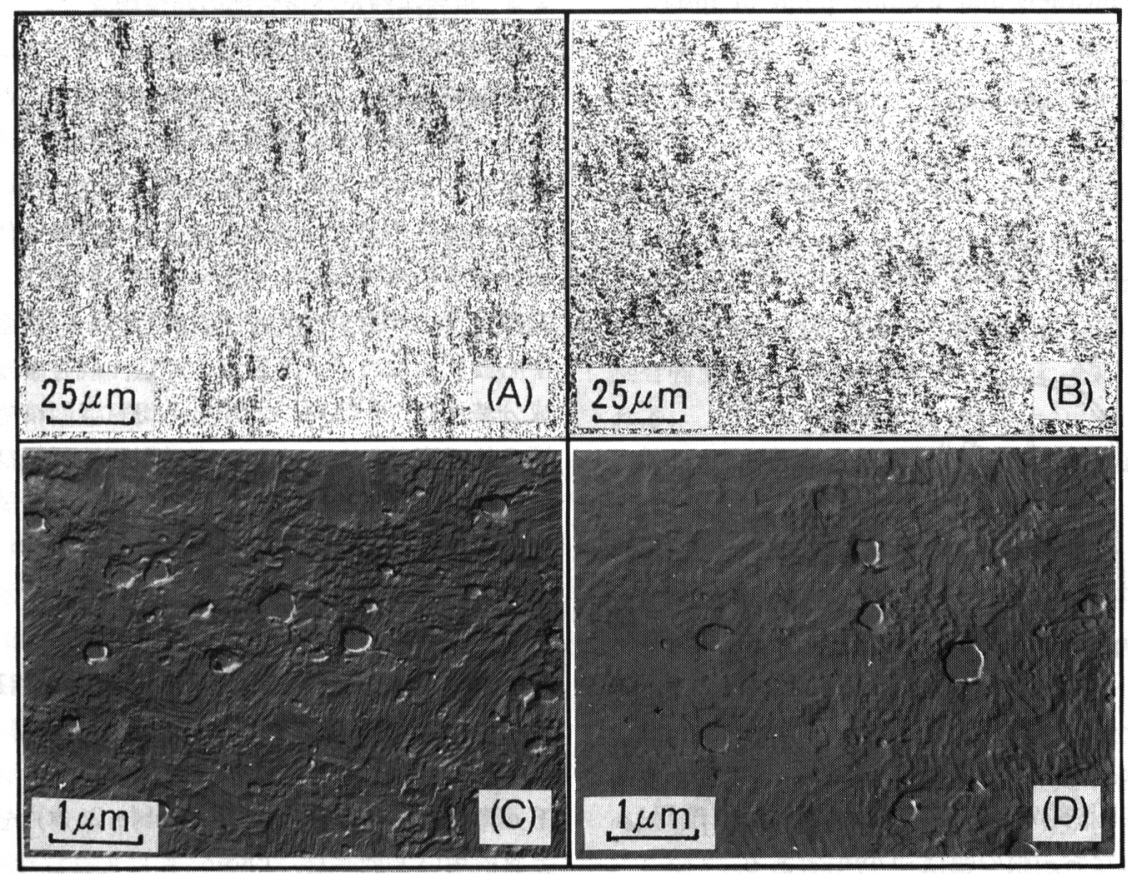

Optical micrographs (A) Longitudinal, (B) Transverse Electron micrographs (C) Longitudinal, (D) Transverse

Photo. 1. Micrographs of ODS alloy (as shipped).

す.この合金は米国 Huntington Alloy 社より購入した $\mathrm{Y}_{2} \mathrm{O}_{3}$ 粒子分散強化 $\mathrm{Ni}$ 基超合金 $\mathrm{MA} \mathrm{7541)2)} \mathrm{である.}$ この合金はメカニカルアロイングと称する方法で造られ ており，大まかにい党ば，金属・合金粉末と $\mathrm{Y}_{2} \mathrm{O}_{3}$ 粒子 の均等混合, 焼結処理, 押出加工, ついで溶体化熱処理 $\left(1316^{\circ} \mathrm{C} \times 0.5 \mathrm{~h}\right)$ が施されている. 本研究に用いた母 材の組織を Photo. 1 に示す. Photo. 1 (A) から組織 は押出加工方向に伸びて繊維状を呈していることがわか る.このため, 試験片の採取方向による著しい性質の違 いが認められている12). 電子顕微鏡写真 $(\mathrm{C})$ ，(D) そは $0.2 \sim 0.4 \mu \mathrm{m}$ の大きさの粒子が認められ，EPMA によ る元素分析によれば主成分は分散粒子の $\mathrm{Y}_{2} \mathrm{O}_{3}$ である。

\section{$2 \cdot 2$ インサート金属}

インサート金属に含まれる融点降下元素など構成成分 を何にするかは接合強度にかかわるだけに重要である。 本研究では融点降下元素として拡散速度及び薄膜形成能 の点から $\mathrm{B}, \mathrm{Si}, \mathrm{Ge}$ を選定し，基地成分は母材主要成 分の $\mathrm{Ni}$ と $\mathrm{Cr}$ にて構成した。融点降下元素 $\mathrm{Si}$ と $\mathrm{Ge}$ は Ni 中でBよりも拡散が遅いとみられた13)ので，含有 量を迎え B と併用することにし，Table 2 に示す組成を 決めた。
Table 2. Chemical composition of insert metals.

\begin{tabular}{c|c|c|c|c|c|c|c|c|c|c}
\hline \multirow{2}{*}{ No. } & \multicolumn{9}{|c|}{$\mathrm{wt} \%$} & \multicolumn{6}{c}{ at $\%$} \\
\cline { 2 - 12 } & $\mathrm{Ni}$ & $\mathrm{Cr}$ & $\mathrm{B}$ & $\mathrm{Si}$ & $\mathrm{Ge}$ & $\mathrm{Ni}$ & $\mathrm{Cr}$ & $\mathrm{B}$ & $\mathrm{Si}$ & $\mathrm{Ge}$ \\
\hline $\mathrm{A}$ & 76.0 & 20.0 & 4.0 & - & - & 63.2 & 18.8 & 18 & - & - \\
\hline $\mathrm{B}$ & 73.7 & 21.8 & 4.5 & - & - & 60 & 20 & 20 & - & - \\
\hline $\mathrm{C}$ & 72.4 & 21.4 & 3.3 & 2.9 & - & 60 & 20 & 15 & 5 & - \\
\hline $\mathrm{D}$ & 69.3 & 20.4 & 3.2 & - & 7.1 & 60 & 20 & 15 & - & 5 \\
\hline
\end{tabular}

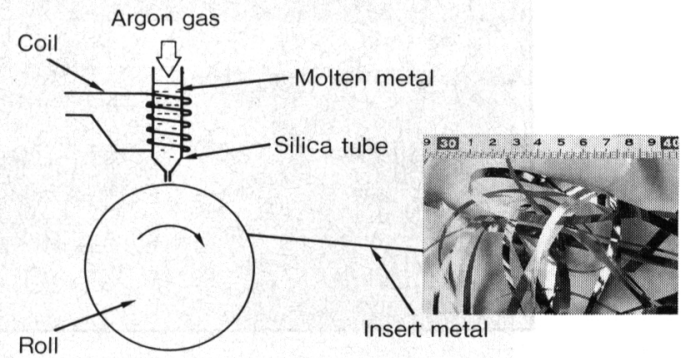

Schematic view

Fig. 1. Manufacturing method of insert metal.

Fig. 1 に示す片ロールによる溶湯の超急冷凝固法に より非晶質薄膜（りぼん）を製作した。得られたりぼん 
Table 3. Thickness and melting point of insert metals.

\begin{tabular}{c|c|c}
\hline No. & Thickness $(\mu \mathrm{m})$ & Melting point $\left({ }^{\circ} \mathrm{C}\right)$ \\
\hline A & 20 & 1029 \\
\hline B & 20 & 1040 \\
\hline C & 18 & 1032 \\
\hline D & 22 & 1005 \\
\hline
\end{tabular}

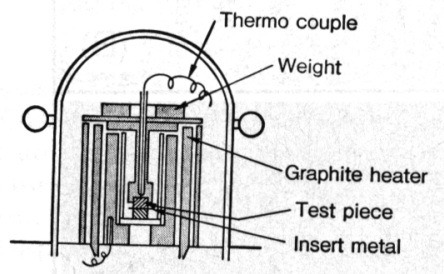

Fig. 2. Experimental apparatus for diffusion bonding.

の膜厚と融点を Table 3 飞示す. 膜厚は $20 \mu \mathrm{m}$ 前後 と極薄である.非晶質かどらかをX線回折により確認し，

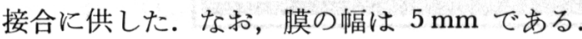

\section{$2 \cdot 3$ 接合実験及び接合部の特性調查}

接合飞先立ち, ODS 合金接合面及びインサート金属 の脱脂処理としてアセトンで超音波洗浄した．接合面間 にインサート金属を挿入した後，接合面の位置ずれ防止 のためステンレス薄板で囲つた，接合に用いた試験片は $12 \mathrm{~mm} \phi$ の円柱で, 接合面は $1 \mu \mathrm{m}$ の加工仕上げを行つ た。接合炉は Fig. 2 のとおりで, 加圧力 $1 \mathrm{kgf} / \mathrm{cm}^{2}$, 真空度 $5 \times 10^{-5}$ Torr で実験を行つた. 接合後, 試料の 中心縦断面につき, 接合部の組織, 成分濃度を調べた。 成分濃度は，EPMA を用い，母材濃度に対するX線強 度の比で表示した．また，高温引張性質及びクリープラ プチャ寿命などの機峨的性質を調査した。試験片はいず れも平行部 $6 \mathrm{~mm} \phi$, 標点間距離 $24 \mathrm{~mm}$ のものである.

\section{3. 実験結果及び考察}

\section{1 インサート金属成分と母材成分との相互拡散}

$3 \cdot 1 \cdot 1$ 接合組織に及ぽす接合時間の影響

ODS 合金の液相拡散接合状態を，まず，B を融点降 下元素とした非晶質りぼん（Table 2, A) をインサート 金属に用いて調べた. Photo. 2 は接合温度 $1200^{\circ} \mathrm{C}$ で

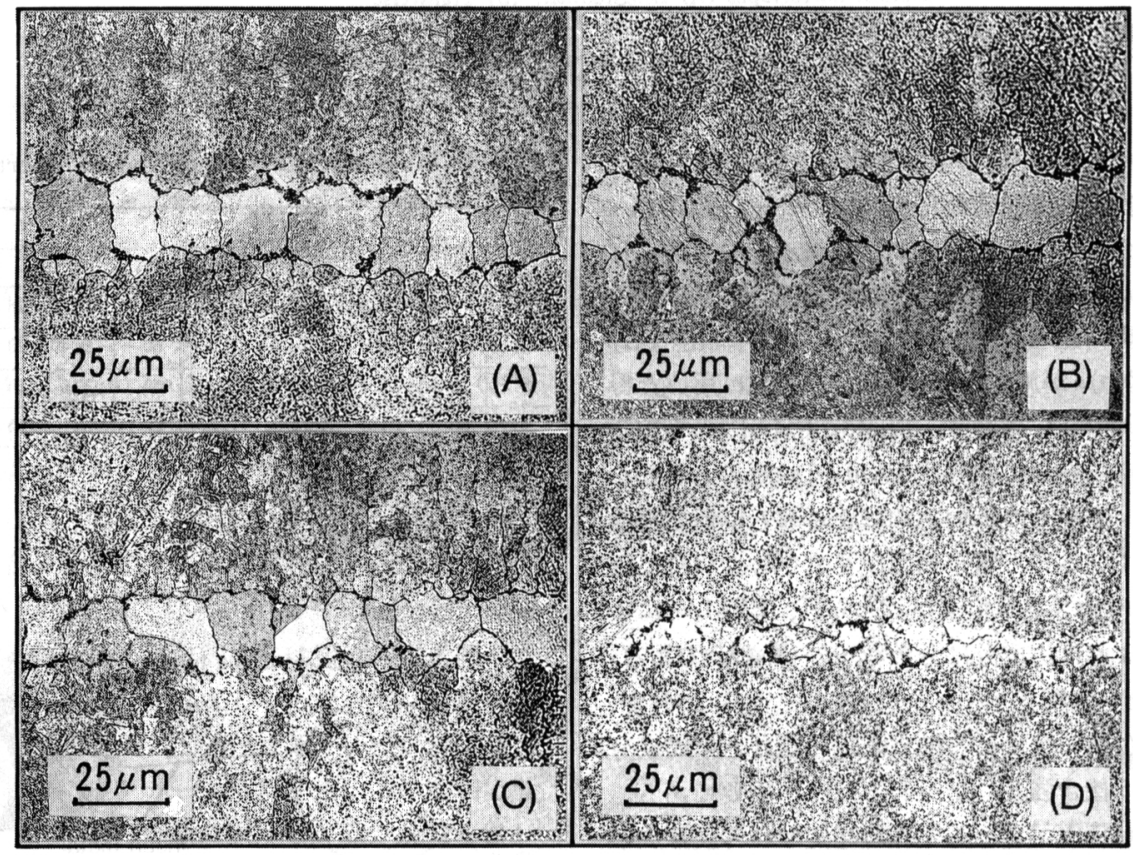

$\begin{array}{lrr}\text { (A) Bonding time } 0.5 \mathrm{~h} \\ \text { (B) } & \text { " } & 1 \mathrm{~h} \\ \text { (C) } & \prime & 10 \mathrm{~h} \\ \text { (D) } & \text { " } & 20 \mathrm{~h}\end{array}$

Insert metal $\mathrm{A}: \mathrm{Ni}-\mathrm{Cr}-\mathrm{B}$ amorphous ribbon

Photo. 2. Effect of bonding time on micro structures formed by the liquid phase diffusion bonding at $1200^{\circ} \mathrm{C}$. 
接合時間を $0.5 \mathrm{~h} \sim 20 \mathrm{~h}$ に変えた場合の 接合組織であ る. 組織上, インサート金属を介在させた接合部は帯状 を呈している．この部分は長時間になるほど不明瞭とな り，インサート金属が母材一拡散進行寸る様子がらかが われる。

接合部には収縮孔欠陷もなく，良好な接合状態であつ た. 接合部の結晶粒に注目すると，接合が $0.5 \mathrm{~h}$ と短時 間の場合，結晶粒は接合面に対して垂直に並び，接合時 間が長くなれば等軸的なものに変わつている。ここでの 結晶粒は等温凝固過程に生成した一次晶とみられる.

\section{1 .2 接合部の分散粒子の凝集}

Photo. 3，(A)，(B) はレプリカ法による電子顕微鏡 組織を示す. (A)は母材部で, 円形の $\mathrm{Y}_{2} \mathrm{O}_{3}$ 分散粒子は $0.2 \mu \mathrm{m}$ 程度の大きさである.（B)は接合部で，粒界に は $1 \mu \mathrm{m}$ を超觉る大きさの化合物が認められた．この化 合物は EPMA による元素の分析によれば，分散粒子の $\mathrm{Y}_{2} \mathrm{O}_{3}$ と $\mathrm{Al}, \mathrm{Ti}$ の酸化物であることが分かつた.

接合部の粒界にこのような化合物が集合した理由とし て以下のことが考えられる. 高温加熱時, 接合面間のイ ンサート金属が溶解し，接合面間が融液で満たされる.

このとき，インサート金属中の B 元素が母材側へ拡散し ていき,母材表面及びその極く近傍部の融点が下がつて， 溶融状態となる.この溶融部には当然, 多くの $\mathrm{Y}_{2} \mathrm{O}_{3}$ 粒
子が眯濁しているが，粒子同志が吸着し合つて粗大化す ると考えられる. そして, 時間の経過にともなつて等温 凝固が進み, 粗大化粒子が凝固前面の結晶粒界に凝集し たものと思われる. この粗大粒子に，母材中の Al， Ti を含む化合物や，接合時生成した $\mathrm{Al}, \mathrm{Ti}$ の酸化物が吹 着し，さらに大きな化合物粒子になつたと解釈できる. これら化合物粒子の凝集を抑制することは，接合界面を 等温凝固せしめて接合する本接合法では困難とみられ, 接合強度，とくに高温下での強度に及ぼす影響が懸念さ れる。

$3 \cdot 1 \cdot 3$ 接合部の元素濃度及びタかけの拡散係数

接合部の成分均一化をみるべく，インサート金属成分 と母材成分との相互拡散状況を調査した。ここでは，接 合温度と時間を変えたときの母材に含まれる $\mathrm{Al}, \mathrm{Ti}$ が 接合界面へどの程度拡散しているかを究明した。なお， $\mathrm{Al}, \mathrm{Ti}, \mathrm{Fe}$ はインサート金属には含まれていない。

Fig. 3 及び Fig. 4 に Al 及び Ti の母材濃度 $\left(C_{0}\right)$ に対する接合部中央の濃度 $(C)$ の比率を示す. 接合部 の濃度上昇は $\mathrm{Ti}$ よりも $\mathrm{Al}$ の方が速いことが分かつ た．例えば, $1200^{\circ} \mathrm{C}$ で接合した場合，接合部の濃度が 80\% 以上になる時間は $\mathrm{Al}$ が約 $5 \mathrm{~h}, \mathrm{Ti}$ が約 $10 \mathrm{~h}$ で あつた・

ここで, それぞれの元素の濃度比をもとに, 母材から

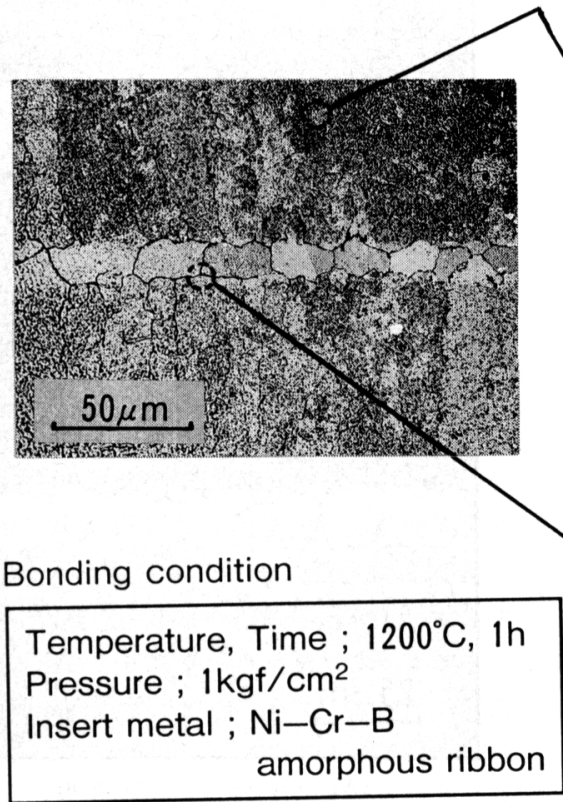

(A) Base metal

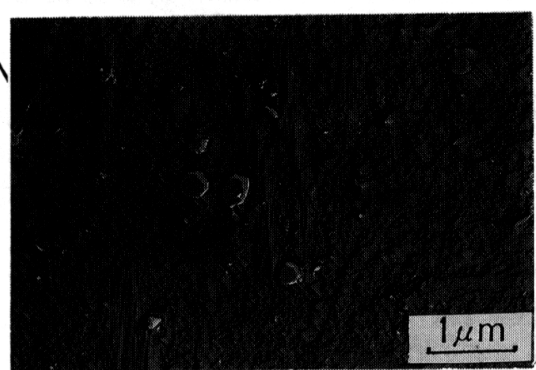

(A)

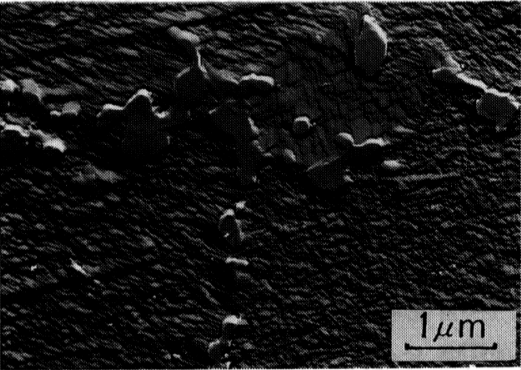

(B)

Photo. 3. Micrographs of bonded region. 


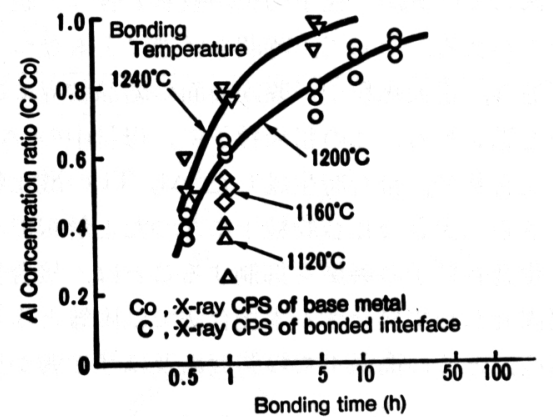

Fig. 3. Effect of bonding time on concentration ratio of $\mathrm{Al}$.

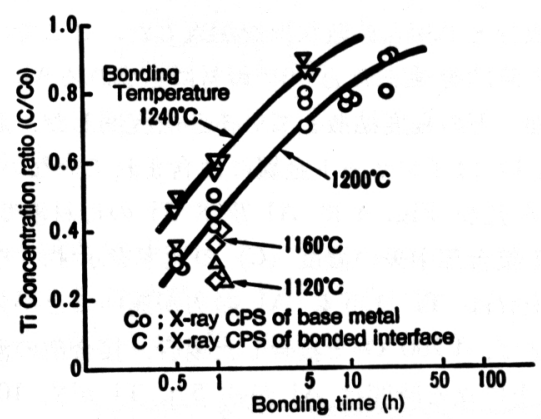

Fig. 4. Effect of bonding time on concentration ratio of $\mathrm{Ti}$.

接合界面へ侵入するときのみかけの拡散係数を算出し

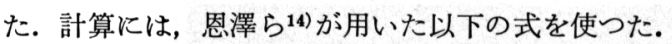

$$
D=\frac{h^{2}}{4 \pi t}\left(1-\frac{C_{0}}{C_{P}}\right)^{2}
$$

ここで, $D:$ 拡散係数, $h:$ インサート金属の厚さ, $t:$ 接合時間, $C_{\boldsymbol{0}}$ : 接合部中央の濃度, $C_{P}$ : 母材部の初期濃 度である。な拉，この式は，逐次近似法によつて，Dの 濃度依存性や粒界拡散の影響を無視し, Fick の第 2 則 に従つた体拡散が起こるとして導かれている. Fig. 5 に算出結果を示す。 この図には Fe についても併記して あり, $\mathrm{Fe}$ は $\mathrm{Al}, \mathrm{Ti}$ よりも $D$ が大きく,かり, 温度 依存性も大きいことが分かつた，過去，我々が実験で得 た $r^{\prime}$ 相析出強化 $\mathrm{Ni}$ 基超合金 IN 738LC の Al そつ いて Fig. 5 中にプロット（○印）してある.これより MA 754 ODS 合金の $D$ は IN 738LC の場合よりる 大きいことがわかる. 例壳ば, IN 738 LC 材で 1200 ${ }^{\circ} \mathrm{C}$ 接合の場合，接合部に $\mathrm{Al}$ が $80 \%$ 濃化する時間は 約 $1 \mathrm{~h}$ であり, ODS 合金よりも相当速い状態にある. ODS 合金で母材から接合部へ払散が遅くなる理由とし ては, マトリクスの分散粒子の影響が大きいと考党られ る.

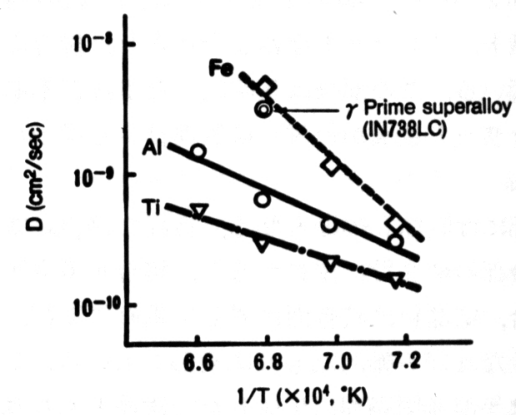

Fig. 5. Calculated results of apparent diffusion coefficient.

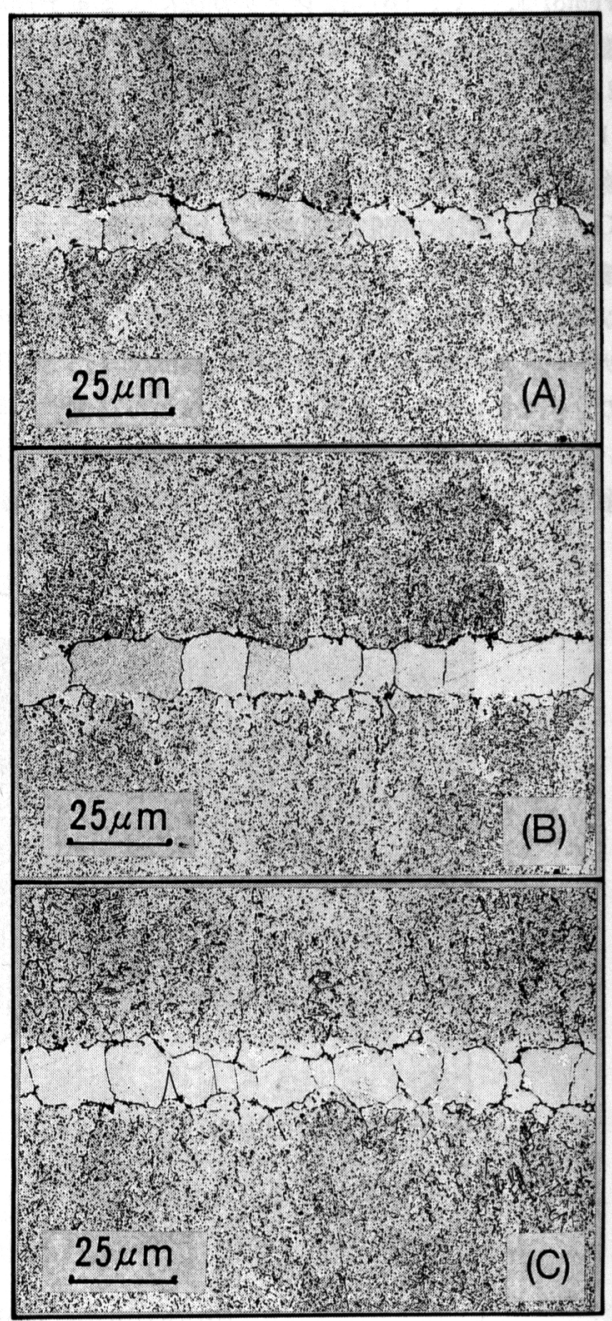

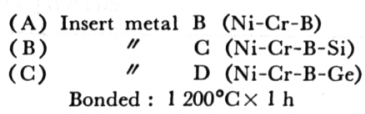

Photo. 4. Effect of insert metal on microstructures of Liquid phase diffusion bonded specimens. 


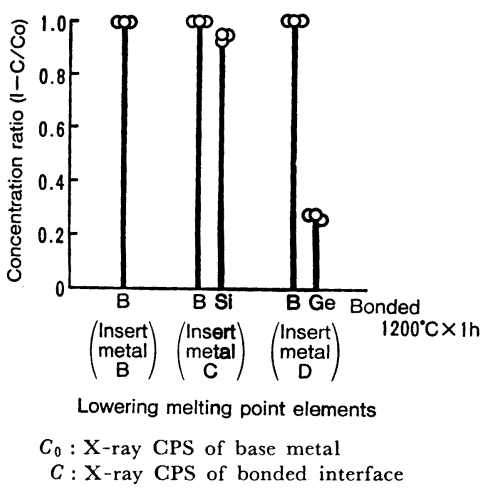

Fig. 6. Concentration ratio of lowering melting point elements in Liquid phase diffusion bonded specimens.

\section{2 融点降下元素を変えたインサート金属による液相 执散接合性}

$3 \cdot 2 \cdot 1$ 融点降下元素の桩散状況

融点降下元素を $\mathrm{B}, \mathrm{B}+\mathrm{Si}, \mathrm{B}+\mathrm{Ge}$ と変えた場合の非 晶質りぼん（Table 2, B D ) をインサート金属に用 い, $1200^{\circ} \mathrm{C}$ で $1 \mathrm{~h}$ 液相払散接合した. 加圧力, 真空度 は前と同じである，接合組織を Photo. 4 亿示す．いず れのインサート金属を用いても，前と同様，接合部粒界 に分散粒子などの化合物の凝集が認められたが，欠陷は なく,よく接合されていた。なお，組織からは 3 者の払 散状況の差異は明らかでなく, インサート金属に添加し た融点降下元素の接合部からの拡散状況を調べた。

Fig. 6 に融点降下元素の扗散度合を示す. インサー ト金属 Bでは融点降下元素としてBのみ用いたが，接合 部からはほほ $100 \%$ 払散している.インサート金属 Cの 融点降下元素は B と Si 元素の併用であり, B元素は母 材へほぼ 100\% 扗散しているが, Si の扗散量は約 95\% であり，Si はわずかに残留している．インサート金属 DではB元素と併用した $\mathrm{Ge}$ 元素の扗散量は約 $30 \%$ で あり, Ge 元素の残留が相当多い結果を得た.

\section{$3 \cdot 2 \cdot 2 \mathrm{Al}, \mathrm{Ti}, \mathrm{Fe}$ の接合部の濃化状況}

次に, 母材中の $\mathrm{Al}, \mathrm{Ti}, \mathrm{Fe}$ が接合部へ払散侵入する 状況をみた. Fig. 7 は母材と接合部中央との濃度比よ り, 前と同じ算出方法でみかけの扗散係数を求めた結果 である. 各元素ともに, インサート金属 B とインサート 金属 $\mathrm{C}$ と払散係数の差はわずかであり, 接合部への濃 化は同程度といえよう. 一方, インサート金属 Dの払散 係数は， $\mathrm{Al}, \mathrm{Ti}, \mathrm{Fe}$ ともに，他のインサート金属より も低い値であり，接合部への濃化速度は小さい。

骶点降下元素にBと Ge を併用したインサート金属 $\mathrm{D}$ は，融点が最も低く好ましいと思われたが，上述のと㧊

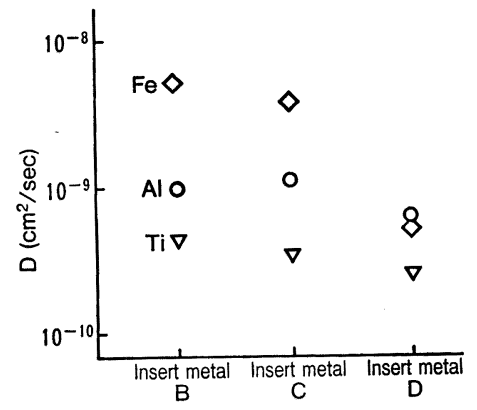

Fig. 7. Calculated results of apparent diffusion coefficients of $\mathrm{Fe}, \mathrm{Al}$, Ti.

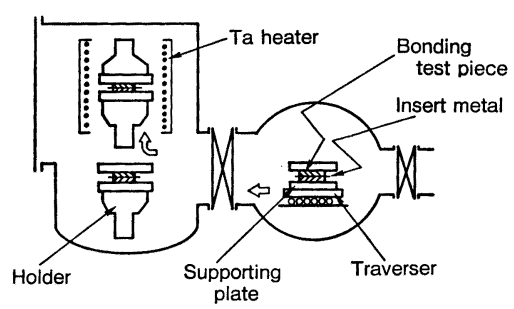

Fig. 8. Schematic view of bonding furnace.

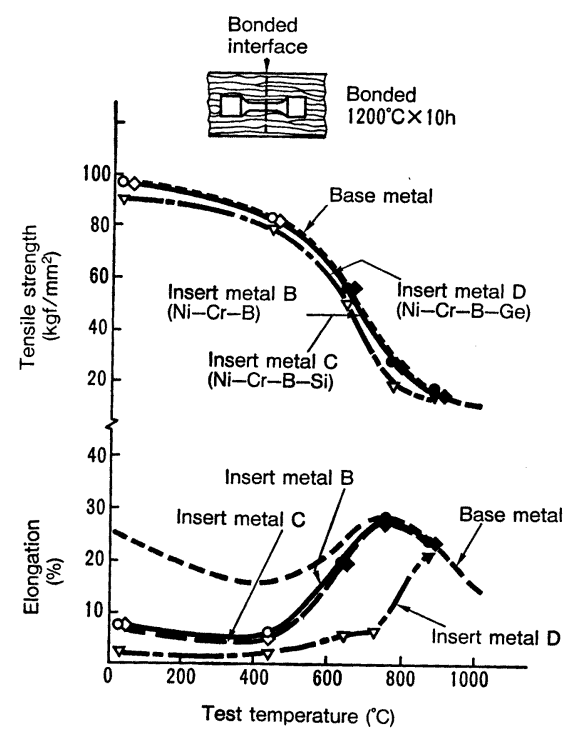

Open marks : Fractured at bonded interface Closed marks : Fractured at base metal

Fig. 9. Effect of chemical compositions of insert metal on tensile properties of bonded ODS alloy at elevated temperatures.

り，インサート金属と母材との相互成分拡散の速度が遅 いので，接合後の拡散時間を長くとる必要がある.

$3 \cdot 2 \cdot 3$ 接合部の機械的性質に及ぼす融点降下元素の 影響 


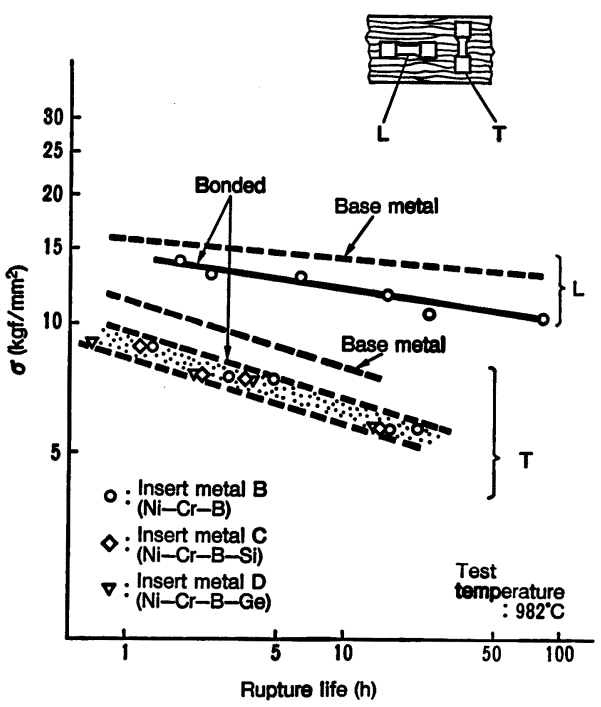

Fig. 10. Effect of chemical compositions of insert metal on creep rupture strength of bonded ODS alloy.

液相扗散接合した接合部の機械的珄質を, Fig. 8 に 示す大型の接合炉を用いて調査した。接合は加厈力 1 $\mathrm{kgf} / \mathrm{cm}^{2}, 1200^{\circ} \mathrm{C} \times 10 \mathrm{~h}$ で行つた. Fig. 9 にインサー ト金属中の融点降下元素を変えた場合の高温引張性質を 示す. 引張強さはインサート金属 Dで母材より若干低目 である、インサート金属 B と C との差はほとんどなく， またこれら強さの值は母材と同等である．Fig. 9 には 接合部破断と母材部破断とを区別して表示した。母材部 破断となることにより伸び值は改善される，接合部破断 から母材部破断へ移行する温度はインサート金属 B，C ともに約 $500^{\circ} \mathrm{C}$ である。一方，インサート金属Dでは， より高温側へずれて約 $800^{\circ} \mathrm{C}$ となる結果を得た。

Fig. 10 に $982^{\circ} \mathrm{C}$ 試験でのクリープラプチャ寿命を 示す. 接合材のラプチャ応力は, 押出加工方向に直角及 び平行な試験片ともに，母材值の約 $85 \%$ を示した. ラ プチャ寿命に対するインサート金属成分の影響は, 破断 位置が母材部であるため，明確でない。

高温で接合部破断から母材部破断へ移行するのは，接 合部と母材部とで強さに対する温度依存性が異なること によつて，高温では母材部より接合部が強くなるためと 考えられる.インサート金属Dの場合，母材部破断へ移 行する温度がより高温へずれる理由は, 融点降下元素 $\mathrm{Ge}$ 及び母材成分 $\mathrm{Al}, \mathrm{Ti}, \mathrm{Fe}$ の濃度測定結果で示した ように，インサート金属と母材との相互成分拡散が遅か つたことによると考えられる. $982^{\circ} \mathrm{C}$ 試験によるクリー プラプチャ破断部が，接合部でなく，母材部であつたこ
とは, 非晶質りぼんによる本液相払散接合が，この ODS 合金に十分適用できるものとみなせる. 一方, ラプチャ 寿命は母材部破断にもかかわらずもともとの性質の約 85\%にとどまつた。 その原因として接合時, 高温長時間 処理によりこの ODS 合金の特性が失われることが考党 られる. しかし熱劣化状況については, 従来明確でなく, 今後十分調榃する必要がある。

\section{4. 結}

高温耐熱性に優れ，次期ガスタービン翼材として注月 される $\mathrm{Y}_{2} \mathrm{O}_{3}$ 分散強化 $\mathrm{Ni}$ 基 ODS 合金 (MA 754) を，2〜3 の融点降下元素入り柯薄非晶質りぼんをイン サート金属に用いて液相扗散接合し，接合組織，成分濃 度及び機械的性質を調べた。その結果，以下の結論とな る.

1 ）等温凝固過程に凝集したとみられる $\mathrm{Y}_{2} \mathrm{O}_{3}$ 分散䉼 子, $\mathrm{Ti} \cdot \mathrm{Al}$ の化合物が接合部の結晶䊉界に集合したが, 空隙欠陷のない健全な接合部が得られた。

2 ) インサート金属と母材との相 $\boldsymbol{H}_{i}$ 成分払散は, $\gamma^{\prime}$ 相 強化 $\mathrm{Ni}$ 基超合金 IN 738LC よりも避い速度であり, 接合後, 拡散時間を長くする必要がある.

3 ) インサート金属中の融点降下元素を B， B $+\mathrm{Si}, \mathrm{B}$ $+\mathrm{Ge}$ と変えた場合，耿材成分 $\mathrm{Al}, \mathrm{Ti}, \mathrm{Fe}$ の接合部への 拡散は, $\mathrm{B} 及 ひ ゙ ~ B+S i$ 含有インサート金属では同程度 の速さである，最も低融点を示した $\mathrm{B}+\mathrm{Ge}$ 含有インサ 一ト金属では，母材成分 $\mathrm{Al}, \mathrm{Ti}, \mathrm{Fe}$ の拡散が遅く，か つ, 融点降下元素 Ge の母材一の払散も遅い結果を得た.

4 ) 引張試験による破断部は高温で接合部から母材部 一移行する。この移行する温度は融点降下元素が $\mathrm{B}$ 及び $\mathrm{B}+\mathrm{Si}$ のインサート金属のとき約 $500^{\circ} \mathrm{C}$ である. $\mathrm{B}+$ $\mathrm{Ge}$ のインサート金属では約 $800^{\circ} \mathrm{C}$ と高温側へずれる. 母材破断となることより，伸び傎が改善される.

5 ）母材部破断である $982^{\circ} \mathrm{C}$ クリープラプチャ寿命 は母材の約 $85 \%$ 以上が確保でき, ODS 合金へ本液相 払散接合法が適用できる見通しが得られた。

なお, 本研究は, 通商産業省工業技術院推進のムーン ライト計画に基づき，高効率ガスタービン技術研究開発 の一環として実施した。

\section{文献}

1) T.J. Kelly: Joining Procedures for MA Products (1982) [INCO]

2) Huntington Alloys Magazine (1977) May, [Huntington Alloy]

3) J. C. Freche and G. M. Ault: Superalloys Metallurgy and Manufacture, Proc. 3rd. Int. Symp. (1976), p. 297 
4) T. E. Howson, D. A. Mervyn and J. K. Tien: Metall. Trans., 11A (1980), p. 1609

5 ) $M . E$. Mcalarney, R. M. Arons and T. E. Howson: Metall. Trans., 13A (1982), p. 111

6 ) $D . S$. Durvall, $W . A$. Owczaski and $D . F$. PAulonis: Weld. J. (1974) Apr., p. 203

7 ) G. S. Hoppin and T. F. Berry: Weld. J. (1970) Nov., p. 505

8 ）铪村暁男，恩澤忠男，田村 博：日本溶接学会 誌, 49 (1980) 7, p. 42

9 ) 大橋修, 田沼欣司, 磯田幸务: 日本溶接学会
誌， 51 (1982) 1, p. 69

10）鈴村暁男, 恩澤忠男, 田村 博：溶接学会溶接法 研究委員会 94 回溶接法資料 (1983 年 10 月)

11）中尾嘉邦：溶接学会界面接合研究委員会シンポジ ウム資料 (1985 年 2 月)

12）河合久孝，辻 一郎：耐熱金属材料 123 委員会 研究報告, 23 (1984) 1, p. 21

13)改訂 2 版金属データブック（日本金属学会編） (1984)，p. 24 [丸善]

14) 恩澤忠男, 畠山耕太郎, 田村 博：日本溶接学会 誌, 45 (1976) 8, p. 57 